\title{
碑林区(西安、中国)における高齢者の住居と居住環境に関する考察 CONSIDERATIONS ON DWELLING AND LIVING ENVIRONMENT FOR ELDERLY PEOPLE IN BEILIN DISTRICT OF XI'AN • CHINA
}

\author{
李＼cjkstart慧娟*1, 山岸輝 樹*2, 広田直行*3, 段 煉 孺*4, 布 野修司 ${ }^{* 5}$ \\ Huijuan LI, Teruki YAMAGISHI, Naoyuki HIROTA, \\ Lianru DUAN and Shuji FUNO
}

\begin{abstract}
The objective of this article is to clarify and evaluate living environment, especially space formation of dwelling for elderly people in Xi'an and Shanxi of China based on field studies. This paper concentrate on Beilin District of Xi'an(6 shequ).

The major points we conclude are that, 1. Facilities for the elderly in shequ( community) are not enough and lack of balanced distribution, 2. The dwelling accommodations have a lot of problems in general, especially critical problems for elderlies with disabilities. This paper points out the problems in detail on terms of daily activities(eating, excretion, bathing, moving, sleeping).
\end{abstract}

Keywords: the elderly, living environment, house plan, shequ(comunity), juminweiyuanhui(resident committee), Beilin Qu of Xi'an 高齢者, 居住環境, 住戸計画, 社区, 居民委員会, 西安碑林区

\section{1 はじめに}

\section{1 - 1 研究の背景と目的}

近年の人口調查によれば、中国は急速に高齢化が進行しつつある。 2017 年現在 60 歳以上高齢者は 2.4 億人、高齢化率は $17.3 \%$ でるが、 2030 年には、60 歳以上高齢者は 3.71 億人、高齢化率は $25.0 \%$ に達す る。陝西省はそれより高く $27.3 \% 、(982.9$ 万人)になると予測されて いる。郭志剛ら (2014） ${ }^{1)}$ は、陝西省は、黒竜江省、吉林省、内蒙古、 遼寧省、寧夏についで高齢化のスピードは全国第 6 位であり、“空巣老 人”注1) と呼ばれる子供が同居しない 60 歳以上の高齢者が 2030 年には 8. $97 \%$ (2015 年、 $4.95 \%)$ に、その内 “独居老人”は $1.56 \%$ (2015 年、 $0.79 \%$ ）に増えると予測している。省都である西安市の場合、今後高 齢者が年平均で約 5 万人ずつ増えると予測されている。

中国国務院は、「養老サービス業推進に関する意見 (国務院关于加 快発展养老服務業的若干意見)」(2013 年、国発 35 号)」を発令し、 在宅を基本として、社区居民委員会注 2) が主導し、地域の高齢者施設 が高齢者を支えるという養老サービス体系の基本方針を明らかにし ている。

本研究は、社区居民委員会をべースとする地域の高齢者の生活支 援の一環として、居住環境整備のあり方についての指針を得ること を大きな目的としている。とくに本稿では、高齢者支援を目的と寸る 中国陝西省での調査（「陝西省老年人社区居家照顧服務調査」）をも
とに、社区の高齢者の居住環境に関する特質を明らかにするととも に、特に住居に焦点を当てて、その問題点を明らかにする。

調查は陝西省老齢工作委員会および西安工程大学段煉孺研究室 の協力のもとに実施し、4市から計 22 社区、22 村について注3) (Fig. 1)、 各社区（村）約 35 人程度、計 1417 人（住居実測 637 戸）に調査を 行なった。本稿では西安市の碑林区 2 つの街道における調查（調查 人数は計 201 人、住居実測 73 戸) について考察を行う。

\section{1 - 2 既往の研究}

中国における高齢者の居住環境に関する研究は立ち遅れている。 中国建築学会に「中国建築学会適老性建築学術委員会」が設けられ たのは 2015 年 12 月 18 日である。それ以前に、胡仁禄 $(1995)^{22}$ は 居住環境を高齢者向けに改善し、かつ高齢者施設を整備することが 必要と主張した。そして、曹力鴎（1999） ${ }^{3)}$ は高齢者向けの集合住宅 の理念を提唱した。21 世紀に入って、社区及び在宅で高齢者問題に 取り組む方針が大きな流れとなる中、胡慧琴 $(2004)^{4)}$ は、集合住宅 について「分散近居」(同じ住棟に高齢者世帯と子供の世帯が別層に 住む）を提案した。また、周典 (2009) ${ }^{5)}$ は、在宅ケアと社区におけ る高齢者サービスの充実化を提案する。

日本建築学会では、これまで高齢者の居住環境に関する研究が数 多く積み重ねられている。例えば高齢者の寸まいに関する研究 ${ }^{6), 7)}$ や、地域支援に関する研究 $\left.{ }^{8)}, 9\right)$ 、利便性から見た高齢者の居住環境

\footnotetext{
*1 日本大学大学院生产工学研究科建築工学専攻 博士後期課程

*2 日本大学生産工学部建築工学科 専任講師 ·博士 (工学)

*3 日本大学生産工学部建築工学科 教授・博士 (工学)

*4 西安工程大学都市計画与市政工程学院 教授・博士 (工学)

*5 日本大学生产工学部建築工学科 特任教授・工博
}

Doctoral Course, Dept. of Architecture and Architectural Engineering, Graduate School of Industrial Technology, Nihon Univ.

Senior Lect., Dept. of Architecture and Architectural Engineering, College of Industrial Technology, Nihon Univ., Dr.Eng.

Prof., Dept. of Architecture and Architectural Engineering, College of Industrial Technology, Nihon Univ., Dr.Eng.

Prof., Dept. of Architectural Engineering, College of Urban Planning and Municipal Engineering of Xi'an Polytechnic Univ., Dr.Eng.

Project Prof., Dept. of Architecture and Architectural Engineering, College of Industrial Technology, Nihon Univ., Dr.Eng. 
に関する研究 ${ }^{10)}$ など様々な研究が行われている。しかし高齢居住者 及び居住環境について地域の総体的な課題を明らかにしようとする ものは加藤ら (2006) ${ }^{11}$ による、多摩ニュータウンにおける研究を 除けば数少ない。中国都市部の高齢者の居住環境に関する論文も上 海の高齢者の生活実態に迫った朴ら ${ }^{12)}$ (2012) 等いくつか見られる だけである。本研究は、中国の都市における高龃者の居住環境の実 情を明らかにし、社区を基本単位として高齢者を支援するために、 居住環境と周辺施設の整備方針を明らかにすることを大きな目的と し、本稿では、高齢者の住居と社区の周辺施設の問題点を明らかに するものである。

\section{1 - 3 調査概要}

調査は、以下の a) 〜d）からなる。

a）社区居民委員会管理センター調查 : 社区人口、高齢者人口、 社区が高齢者に提供している施設、空間、サービス内容などに関寸 るヒアリング調查。b）施設分布調查 : 政府機関、老年大学、地域施 設、公園、娛楽活動センター、医療施設、居宅ケアセンター、老年 食堂、救援点、トイレ、スーパー、法律支援センターなど。c）高 齢者へのインタビュー調査：高齢者のプロフィール（年齢、性別、 職業、同居人数、同居関係、収入、支出、婚姻の状況） /生活問題 (身体 (健康) 問題、生活支援、経済的問題、居住環境、子供との 関係、婚姻関係、娛楽、近隣関係） /居住実態（所有形態、建設年 代、階数、居住年代、面積、住宅使用と不満、施設利用状況など） d）住宅調査：間取り、室内家具配置など。

調查は、西安工程大学の段煉孺研究室の学生 20 人の協力によって、 2018 年 6 月 7 日〜 2018 年 7 月 18 日（碑林区は 2018 年 6 月 7 日〜2018 年 6 月 15 日）に行った。

\section{2 碑林区の居住環境}

\section{$2-1$ 碑林区の概要}

西安市中心東南部に位置し、西安旧城（明代西安府城）の内外に わたる碑林区 ${ }^{\text {i部 }}$ は、歴史的な石碑を集めた碑林の名が示すように、 小雁塔、道観八仙庵など古跡のある歴史的地区である。唐時代の「東 市」は今の碑林区圈域の東南部に位置した。清代に入って城内東北 部に「満城 (満州八旗城)」が建設され、その南 (現在の碑林区のあ る南東部）には、関中書院など教育施設が集中していた。現在の碑 林区においても教育施設が集中する。

碑林区は、8つの街道 98 社区からなる（Fig. 1)。碑林区の戸籍人
口は 71.3 万人、常住人口は 62.9 万人である (2016 年)。60 歳以上高 齢者が 12.0 万人、高齢化率は $19.2 \%$ である（2015 年）。

\section{2 - 2 社区の空間構成}

調查対象としたのは、碑林区の旧城内の柏樹林街道 12 社区のう ち菊花園（11)、東大街（2)、馬厂子（3)の３社区と旧城外の東 関南街街道 10 社区のうち曹家巷（4)、東関（5)、金花（6)）の 3 社区、計 6 つ社区である (Fig. 1)。

社区の面積、戸数、人口密度、高齢者 (60 歳以上) 人口等は Table 1 に示すとおりである。高齢化率は 9.8～19.6\%で、西安全体の 16.4\%より高いのは、社区(2)と社区(5)である。人口密度は258～630人 / haであるが、社区(2)(3)(4)(6)には、公共施設、大学、記念館、公園、 商業街、空地（再開発用地）などがあるため人口密度は低い。人口 密度の高い社区(1)5)、高層集合住宅によって構成されている。

社区(1)には、中心に中学校、専門学校がある。13 の国営企業、行 政職員の団地があり、ほぼ半数は 8 階以上の高層集合住宅である。 社区居民委員会の事務所内に会議室、娛楽室、居宅ケアセンター、 高齢者食堂がある (計 $\left.630 \mathrm{~m}^{2}\right)$ 。社区(2)は、東に高層ビルがあり、全 て中層の 8 つの国営企業、行政職員の団地がある。社区居民委員会 の事務所内に娛楽室があるが、居宅ケアセンター、高齢者食堂など はない（計 $300 \mathrm{~m}^{2} ）$ 。西南部に碑林区の住民教育センターがある。社

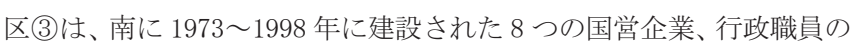
ための中層住宅団地がある。居民委員会事務所内に娛楽室、居宅ケア センターなどがある（計 $600 \mathrm{~m}^{2}$ )。社区(4)には、6つの国営企業、行 政職員の団地があり、 5 つの民間開発団地がある。ほぼ半数は 8 階以 上の高層集合住宅である。社区居民委員会の事務所（計 $380 \mathrm{~m}^{2}$ )、社区 中西部の中層住宅に居宅ケアセンター、高齢者食堂、活動室がある (計 $\left.223 \mathrm{~m}^{2}\right)$ 。社区(5)は、興慶公園に隣接し、社区内には 8 つの国営企業、 行政職員の団地がある。社区居民委員会事務所は独立の 3 階建て建物 で、社区の中心に位置し、娛楽室や図書室、高齢者に向きリハビリ訓

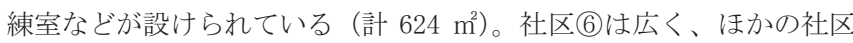
の 2 3 倍である。中に長楽公園、西安工業大学がある。8つの国営企 業、行政職員の団地がある。 8 階以上の高層集合住宅は半数以上であ り、建替えられた団地もある。社区居民委員会事務所は高層住宅の一 層にあり、社区居民委員会の事務所のうちにクリニック、活動室があ る (計 $\left.280 \mathrm{~m}^{2}\right)$ 。

\section{2 - 3 近隣施設の分布状況}

高齢者の日常生活圈としての領域は直線距離で $500 \sim 600 \mathrm{~m}$ 、歩行
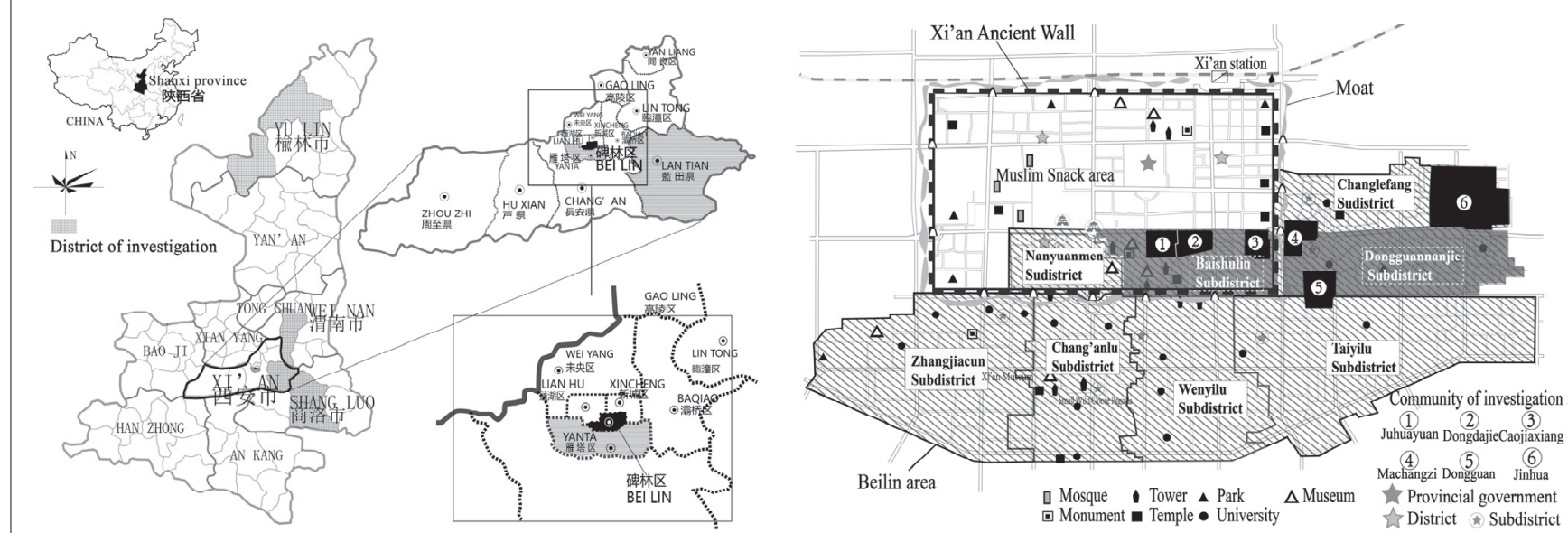

Fig.1 Study Area 
距離 700〜800m、人口で $8000 〜 10000$ 人程度注 5) とされるが、これを 参考に社区の中心（南北端、東西端を結ぶ長方形の中心）から半径 $500 \mathrm{~m}$ 内外の社区の高齢者向け施設（食堂、娛楽室、居宅ケアセンタ 一、法律支援）および社区内外の高齢者が使用できる一般施設（老 年大学 (高齢者生涯教育センター)、診療所・病院、高齢者介護施設、 地域施設、公園、商店）の分布状況は以下の通りである（Fig. 2)。

社区(1)は、高齢者向け施設は社区居民委員会事務所内に設置され、 社区の東に偏っているが、西側に住む高齢者でも徒歩で $450 \mathrm{~m}$ の距 離にある。生活圈内に診療所は東に多くあり、西には 1 箇所しかな い。圏域内に護理院、養老院等の高齢者介護施設注 $\left.{ }^{6}\right)$ はなく、中心か ら直線距離 $1 \mathrm{~km}$ 社区外にはある。社区(2)も、高齢者向け施設は、社 区の中心にある社区居民委員会事務所内に設置されているが、高齢 者向けの食堂や居宅ケアセンターは設置されていない。生活圈の中 に一般施設は数多くあるが、高齡者介護施設はなく、直線距離 $1.2 \mathrm{~km}$ のところに護理院が 1 施設ある。社区(3)は、社区居民委員会事務所は $250 \mathrm{~m}$ 社区外にあり、北部の高齢者にとっては直線距離で $600 \mathrm{~m}$ 以上 離れている。高齢者食堂は設置されていない。社区内に施設は少なく、 診療所、公共トイレは 1 つしかない。圈域内に護理院がある。社区(4) は、高齢者向け施設は、社区居民委員会事務所と別に西の集合住宅 (賃 貸）に設置されている。圏域内に高齢者介護施設はなく、中心から 1 $\mathrm{km}$ の位置に 1 か所ある。社区(5は、公園の近くにあり、社区中心に 高齢者向け施設が集中して設けられており、護理院、老年大学（高 齢者生涯教育センター)、高齢者向け食堂がある。南に住んでいる高 齢者は、交通量の多い道路を陸橋で越えて施設を利用している。社 区(6)は、社区居民委員会事務所は北西に設置され、最も遠い利用者 は直線距離で $800 \mathrm{~m}$ 以上ある。社区内にも、社区外周辺にも高齢者介 護施設がない。また、食堂、居宅ケアセンターもない。南部に診療 所は少なく、西南部に診療所はない。

\section{3 高齢者の生活状況}

高齢者へのインタビュー調査は、各社区から 60 歳以上の高齢者 25 ～35 人を居民委員会の協力によって選定した。調査対象は、柏樹林街 道 92 人 (1) 21 、(2) 35 、(3) 36 )、東関南街街道 109 人 (4) 36 、(5) 34 、(6) 39)、計 201 人（男性 72 人、女性 129 人）である。

\section{3-1基本属性}

調查対象高齢者の年齢は 60 歳 97 歳で、平均年齢は 77.5 歳、社 区による大きな違いはない。平均居住年数は 26.0 年、社区(1)(2)は 30 年を越え、他の社区は 22. 5 25. 1 年である。 $88.1 \%$ 無職であり、そ のうち、56.2\%は国営企業の退職者、平均収入は 3139.1 元/月である。 家族人数は $1 \sim 8$ 人であり、「独居老人」 $(\mathrm{S})$ は 38 世帯 $(18.9 \%)$ (1) 23.8 , (2) 20.0 , (3) 27.8 , (4) 25.0 , (5) 5.9 , (6) 12.9 )、「独身老人十子

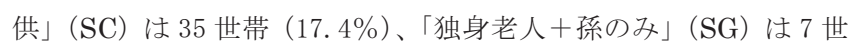

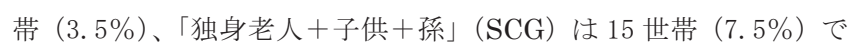
ある。「夫婦の夕」（D）は 80 世帯 (39.8\%) (11)38.1, (2)42.9, (3) 41.7, (4) 41.7, (5) 32.3 , (6) 46.2 )、「夫婦十子供」(DC) は 6 世帯 (3. $0 \%)$ 、「夫婦十子供十孫」(DCG) 10 世帯 $(5.0 \%)$ 、「夫婦十孫 の夕」(DG) 2 世帯 $(1.0 \%)$ 、その他 8 世帯の中「独身老人十へル パー」 $(\mathrm{SH})$ は 6 世帯 $(3.0 \%)$ 、独身老人十子供十ヘルパー」 $(\mathrm{SCH})$ は 1 世帯 $(0.5 \%)$ 、「夫婦十子供十ヘルパー」(DCH) 1 世帯 $(0.5 \%)$ である。

\section{3 - 2 日常活動}

日常生活において、住居外で過ごす時間は平均 4.3 時間 (1) 4.4 、 (2)3.1、(3)4.0、(4)3.6、(5)6.7、(64.0) であるが、社区(5)は高齢者施 設が充実しており、高齢者は日中ほとんど住居外で過ごしている。 使用されているのは、公園 $62.7 \%$ 、娛楽活動室 $14.8 \%$ 、運動場 $12.4 \%$ 、 高齢者施設（居宅ケアセンター、リハビリ室など） $5.7 \%$ 、老人大学 (生 涯教育センター） $2.4 \%$ 、元職場 $1.9 \%$ である(複数回答)。

\section{3 - 3 抱えている問題}

生活上の心配事、問題点について、全く問題ないと答えた人は 39. 3\%で、60.7\%は何らかの問題を抱えている。a.身体健康医療問題 b. 生活支援 $\mathrm{c}$. 経済的問題 $\mathrm{d}$. 居住環境の問題 $\mathrm{e}$. 家庭問題（婚姻関係・子 供との関係） f. 娛楽活動 g.近隣関係の順に割合が高い(複数回答)。 社区(5)は、全く問題ない高齢者が半数を超えるが $(51.2 \%)$ 、社区(4) は、97.2\%がなんらかの問題を抱えている。また、社区(1) 経済的 問題を抱えている高齢者が 23.3\%いる（Fig. 3)。

a. 身体健康医療問題として、78.1\%の高齢者は慢性病を患っている。 b. 生活支援として、実際利用されているのは、食費支援の食堂、連 絡通信、訪問家事、訪問診療である。また、要望が高いのは、食費支 援の食堂、訪問家事、訪問診療以外の病院同行、訪問介護、リハビリ 治療である（Fig. 4)。将来の介護支援について、「心配」＋「非常に心 配」を合わせると $26.4 \%$ となる。社区(5)は、心配の度合いがやや少な い(Fig. 5)。一方、他人を支援したい高齢者が $76.0 \%$ にぼる、社区内 での相互扶助の可能性があると考えることができる。c. 収入源は、退 職金 59.1\%、福祉補助 $22.6 \%$ 、子供の援助 $10.4 \%$ 、勤労所得 $5.0 \%$ 、配 偶者の所得 $1.8 \%$ である。支出は、日常生活費 $51.3 \%$ 、医療費、薬代 $32.6 \%$ に達する。再就職を希望しないのは $75.6 \%$ であるd. 住宅で問 題があるのは、トイレ、暖房、日当たり、ガス、シャワー、水道電気、 段差である。狭さや間取り、手寸りがない、台所の設備、水漏れなど の問題が挙げられる(Fig. 6)。社区(2)(3)(6)にはイレに問題があり、 社区(5)には暖房の問題がある。近隣施設として必要されているのは、

Table 1 Basic situation of Shequ

\begin{tabular}{|c|c|c|c|c|c|c|}
\hline Subdistrict & \multicolumn{3}{|c|}{ Baishulin } & \multicolumn{3}{|c|}{ Dongguannanjie } \\
\hline $\begin{array}{c}\text { Shequ } \\
\text { (Community) }\end{array}$ & $\begin{array}{c}\text { Juhua } \\
\text { yuan } \\
\text { (1) }\end{array}$ & $\begin{array}{l}\text { Ma } \\
\text { changzi } \\
\text { (2) }\end{array}$ & $\begin{array}{l}\text { Dong } \\
\text { danie } \\
\text { (3) }\end{array}$ & $\begin{array}{l}\text { Dong } \\
\text { guan } \\
\text { (4) }\end{array}$ & $\begin{array}{l}\text { Caojia } \\
\text { xiang } \\
\text { (5) }\end{array}$ & $\begin{array}{l}\text { Jin } \\
\text { hya } \\
\text { (6) }\end{array}$ \\
\hline \multicolumn{7}{|c|}{ Basic situation of community } \\
\hline $\begin{array}{l}\text { Community } \\
\text { area } \\
\text { knil }\end{array}$ & 0.13 & 0.19 & 0.24 & 0.16 & 0.21 & 0.45 \\
\hline Households & 2600 & 2046 & 2700 & 3280 & 2558 & 6965 \\
\hline Population & 6900 & 5321 & 6185 & 10082 & 6948 & 12472 \\
\hline $\begin{array}{c}\text { Population } \\
\text { density P/ha }\end{array}$ & 530 & 280 & 258 & 630 & 331 & 277 \\
\hline Elderly（p） & 920 & 960 & 794 & 987 & 1338 & 1300 \\
\hline Aging rate $\%$ & 13.3 & 18.0 & 12.8 & 9.8 & 19.6 & 10.4 \\
\hline \multicolumn{7}{|c|}{ Basic situation of community committee } \\
\hline $\begin{array}{c}\text { Community } \\
\text { committee place } \\
\text { area } \\
\text { build/lend } \\
\end{array}$ & $\begin{array}{l}630 / \\
\text { lend }\end{array}$ & $\begin{array}{l}300 / \\
\text { build }\end{array}$ & $\begin{array}{l}600 / \\
\text { lend }\end{array}$ & $\begin{array}{l}603 / \\
\text { lend }\end{array}$ & $\begin{array}{l}624 / \\
\text { build }\end{array}$ & $\begin{array}{l}280 / \\
\text { lend }\end{array}$ \\
\hline Staff $(p)$ & 13 & 11 & 15 & 11 & 13 & 18 \\
\hline \multicolumn{7}{|c|}{ The facility for inner elderly of community (By committee) } \\
\hline $\begin{array}{l}\text { Canteen for } \\
\text { elderly }\end{array}$ & 1 & 0 & 0 & 1 & 1 & 0 \\
\hline Activity room & 1 & 1 & 1 & 1 & 1 & 1 \\
\hline $\begin{array}{c}\text { Home care } \\
\text { center }\end{array}$ & 1 & 0 & 1 & 1 & 1 & 0 \\
\hline $\begin{array}{l}\text { Legalaid } \\
\text { station }\end{array}$ & 1 & 1 & 1 & 0 & 1 & 1 \\
\hline \multicolumn{7}{|c|}{ The facilities for all of elderly in the community(By society ) } \\
\hline School for elderly & 0 & 0 & 0 & 0 & 1 & 0 \\
\hline Clinic/hospital & 2 & 3 & 1 & 2 & 2 & 3 \\
\hline Nursing home & 0 & 0 & 0 & 0 & 1 & 0 \\
\hline Local facility & 0 & 1 & 0 & 0 & 0 & 0 \\
\hline Park/Green & 0 & 0 & 0 & 0 & 0 & 1 \\
\hline Store/Supermarket & 6 & 10 & 6 & 4 & 6 & 15 \\
\hline Toilet & 4 & 2 & 1 & 2 & 1 & 5 \\
\hline
\end{tabular}

committees provide services and venues for the elderly in the region. 


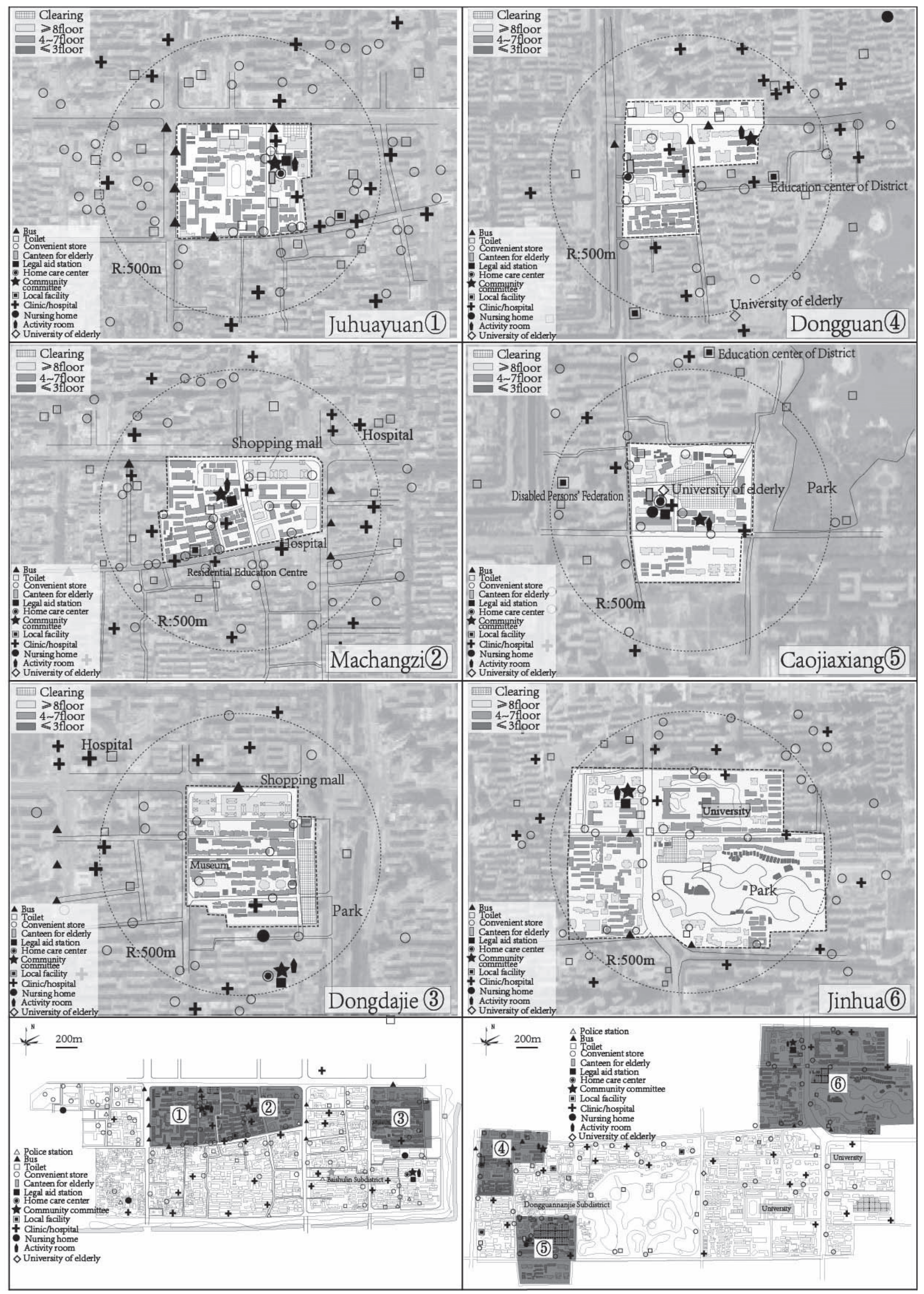

Fig.2 Distribution of Community Facilities in the Vicinity of Shequ 
娛楽施設、病院・診療所の割合が高い。病院・診療所は、社区(1)(2)(3) (4)で、ケアサービス施設は社区(1)(2)で必要性と考える人の割合が高い (Fig. 7)。e. 婚姻や子供との関係など問題を抱えている高齢者は $8.5 \%$ 、夫婦関係が悪い $4.0 \%$ 、扶養矛盾（子供が親の面倒を見る義務 を果たさない) $4.5 \%$ である。子供との同居希望は $48.8 \%$ あ、希望し ないものも $42.3 \%$ あ。孤独感については、しばしば感じる $13.9 \%$ 、

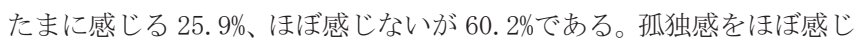
ないが最も多い社区(5) (76.5\%) は、高齢者施設が最も充実している。 f. 娛楽活動を全く行わないものが全体で $72.2 \%$ もなる。中でも社区 (4) (81.1\%)、(6) (81.4\%) は高い。社区居民委員会が企画する娛楽活動 （囲碁、合唱、ダンスなど）について、参加したいのは $54.2 \%$ 、参加し たくないのは $35.3 \%$ ある。娛楽活動に参加しない理由は、主に体が良 くない $53.8 \%$ 、場所が少ない $17.3 \%$ 、興味がない $17.3 \%$ であるg. 近 隣との交流がほとんどないものが全体平均で $66.7 \%$ にの゙る。社区(1) (2)6は 70\%以上が近隣とは交流をもっていない。

以上のように、社区によって高齢者の抱えている問題は異なるが、 一般的に指摘できるのは、近隣と交流が少なく、子供と一緒に住ま ない場合、また、高齢者施設が不足な社区においては、住居外で過 ごす時間が短く、高齢者の孤独感は比較的高いことである。そして、 社区委員会が組織する活動に参加希望が高く、社区委員会への依頼 感が高いことも指摘できる。

\section{4 高齢者の住居}

\section{4 - 1 住居の概要}

調查対象高齢者の住居（全 201 戸）を見ると、各社区とも 1990 年 代に建てられた住宅が最も多く全体で 96 戸 (47.7\%) である。1980 年 以前に建てられた住宅は 19 戸 (9.4\%)、1980 年代に建てられた住宅は 56 戸 $(27.8 \%) 、 2000$ 年以降に建てられた住宅は 30 戸 (14.9\%) である。 ほとんどがエレベーターのない 4〜 7 階注7)の中層集合住宅で 164 戸 (81. 6\%) ある。8 階以上の高層集合住宅は 24 戸 (11.9\%) あるが、そ のうちエレベーターがないものが 5 戸ある。1３階の戸建住宅は 13 戸 $(6.5 \%)$ で、社区(1)に 3 戸ある。家族人数と住戸面積の関係を見る と、一人暮らしでも $30 \mathrm{~m}^{2}-105 \mathrm{~m}^{2}$ の幅があり、2 人で $7 \mathrm{~m}^{2}$ の住宅に住ん でいるものもいれば、158 $\mathrm{m}^{2} の$ 住宅に住む例もある（Fig. 8)。

\section{4- 2 家族類型と住居類型}

調査住居を室構成で類型化すると、最も多いのは $2 \mathrm{LDK} の 114$ 戸 で、3LDK29 戸、1LDK20 戸、2DK14 戸、1R（ワンルーム）10 戸、 $1 \mathrm{DK} 7$ 戸、4LDK7 戸となる。

家族人数と寝室数の関係を見ると、独身老人については、孫(子供、 ヘルパー）と一緒に一寝室に住むなど、三世代で $3 \sim 5$ 人が一寝室や二 寝室の部屋に住むものが約 15\%ある。寝室数が足りない住戸は全体 で 30 戸ある (Fig. 9 の網掛け部分)。

\section{4 - 3 生活自立度と住居}

詳細調查を行った 73 人の高齢者を身体機能・健康に関して、健常 者「自立度 I」：(肢体が自由に補助具なしで動ける)、肢体が不自由 であるが自分で動ける「自立度 II」：(杖、車椅子で単独で動ける)、 肢体が不自由で介護必要「自立度III」：(車いすで介護が必要、寝た きり）の三段階に分けると、「自立度 I」は 38 人、「自立度 II 」は 30 人、「自立度III」は 5 人である。その家族類型と住居類型を自立度別 にみるとの関係をみると以下のようになる（Fig. 10）。

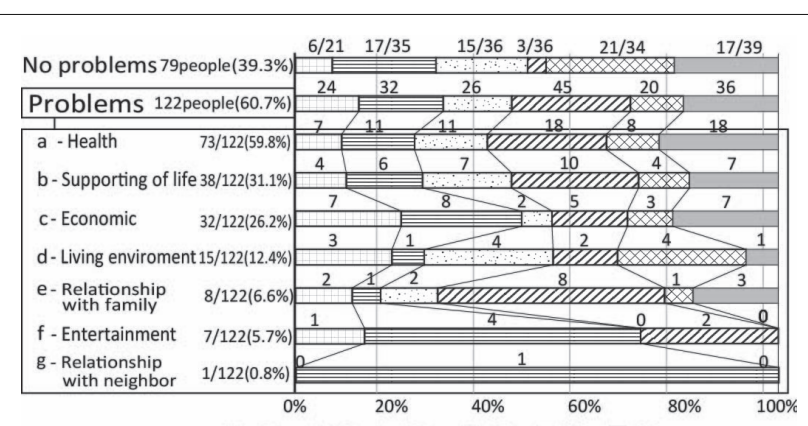

$\square$ (1) 自 (2) $⿴ 囗 3$ (3) (4) (5) $\square$ (6)

Fig.3 Problems in life

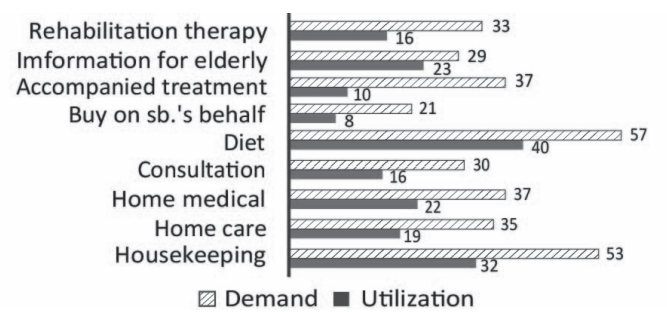

Fig.4 Demand and Utilization about services

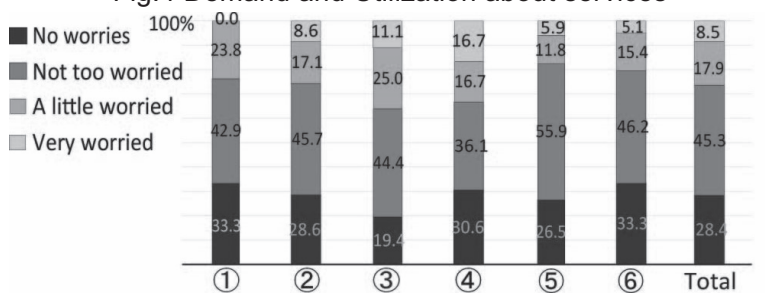

Fig. 5 Concern about future supports

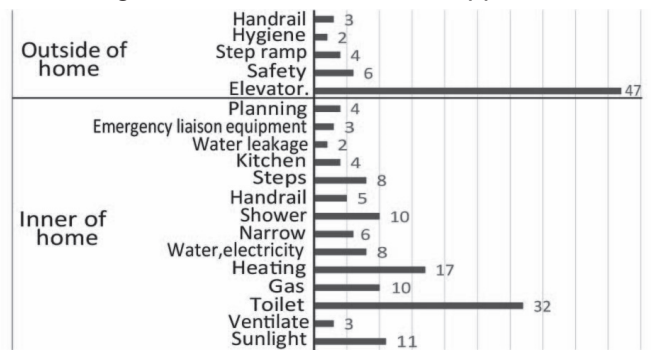

Fig.6 Problems in living environment

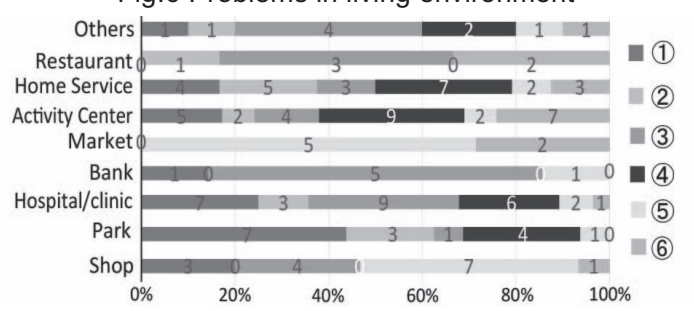

Fig.7 Lack of facilities nearby

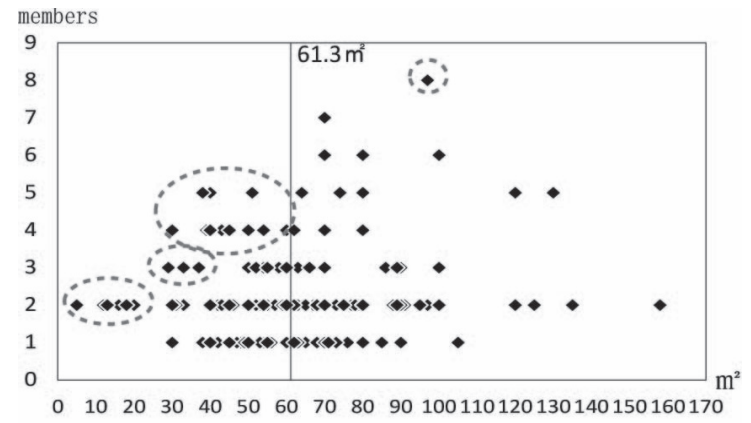

Fig. 8 Family members with dwelling area 
「自立度 I」は家族型(D)タイプの世帯が多く、そのうち 6 戸は 1 寝室の住宅に住み、また $7 \mathrm{~m}^{2}$ 住宅に住んでいる世帯は 1 戸ある。「自立 度 II」には $(\mathrm{S})$ タイプは 9 世帯があり多い。(D)タイプは 8 世帯あ り、そのうち 3 戸は 1 寝室の住宅に住んでいる。(SG)タイプでは 2 世帯が「独身老人と孫のみ」タイプである。(SCG)タイプは 6 世帯 あるが、なかには、 4 人が 1 寝室 (1DK) 住むもの、 8 人が 2 寝室 (2LDK) に住むものがある（ベランダに就寝する）。「自立度III」に は (SC)タイプは 3 世帯あり、( $\mathrm{SCH})$ タイプは 1 世帯あり、そのうち 4 人は $2 \mathrm{DK}$ の住宅に住むことがあり、(D)タイプは 1 世帯がある。

「自立度」により、居住空間における問題は異なる。基本生活行 為としての「食事」、「排泄」、「入浴」、移動」、「就寝」に着目して 全住戸をみると、 $[\mathrm{A}]$ 支障があるもの（自分でことを行えない、危険 となる可能性がある）、[B]不便があるもの（苦労を感じ、時間がか かる)、 $[\mathrm{C}]$ 問題ないものの 3 つに分けることができる。空間使用の 問題点は以下のようである。増築で生じた段差や改造した欴房など は高齢者にとって不便さがみられる。平面図には、増築部、改造部 を示す (Fig. 11)。

自立度 I の高齢者の住戸で支障がある $[\mathrm{A}]$ には、浴槽の高さに支障 があり、3 戸 (12) (30) (31)) で使われていないがある。また室内の移動 は問題ないが、高層階に住んでいてエレベーターがないため買い物

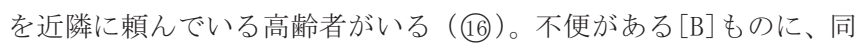

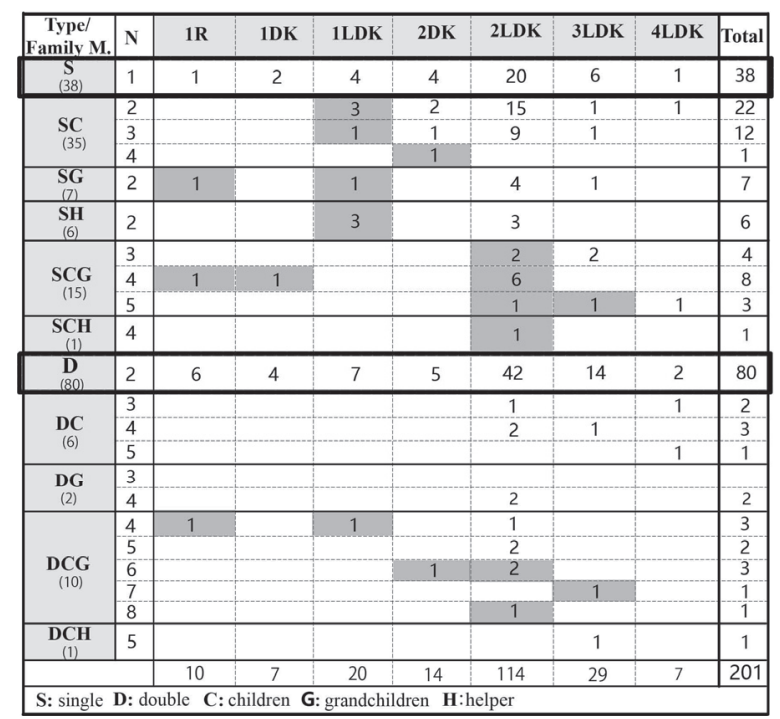

Fig.9 Family type with dwelling type

\begin{tabular}{|c|c|c|c|c|c|c|c|c|c|}
\hline \multicolumn{2}{|c|}{$\begin{array}{c}\text { Type/ } \\
\text { Independence }\end{array}$} & \multirow[t]{2}{*}{$1 \mathrm{R}$} & \multirow{2}{*}{\begin{tabular}{|l|}
$1 \mathrm{DK}$ \\
1 \\
\end{tabular}} & \multirow{2}{*}{\begin{tabular}{|l}
$1 \mathrm{LDK}$ \\
23
\end{tabular}} & \multirow{2}{*}{\begin{tabular}{|l|}
$2 \mathrm{DK}$ \\
4
\end{tabular}} & \multirow[t]{2}{*}{ 2LDK } & \multirow[t]{2}{*}{$3 \mathrm{LDK}$} & 4LDK & \multirow{2}{*}{\begin{tabular}{|c|} 
Tota \\
6
\end{tabular}} \\
\hline \multirow{6}{*}{$\frac{\mathrm{I}}{(38)}$} & $\mathbf{S}$ & & & & & & & & \\
\hline & SC & & & 7 & & 891011 & & & 5 \\
\hline & SG & & & & & 12 & & & 1 \\
\hline & SCG & & & & & 1314 & 1718 & & 6 \\
\hline & D & 19 & 20 & 21222324 & 25 & 26272829303132 & 38 & 33 & 15 \\
\hline & DC & & & & 34 & 353637 & & & 5 \\
\hline \multirow{5}{*}{$\underset{(30)}{\prod}$} & $\mathbf{S}$ & & & 39 & & 4041424344454647 & & & 9 \\
\hline & SC & & & & & 4849505152 & & & 5 \\
\hline & SG & & & & & 5354 & & & 2 \\
\hline & SCG & & 55 & & & 5657585960 & & & 6 \\
\hline & D & & 61 & 6263 & & 6465666768 & & & 8 \\
\hline \multirow{4}{*}{$\frac{\text { III }}{(5)}$} & SC & & & 69 & & 7071 & & & 3 \\
\hline & SCH & & & & 72 & & & & 1 \\
\hline & D & & & & & 73 & & & 1 \\
\hline & & 1 & 4 & 11 & 4 & 49 & 3 & 1 & 73 \\
\hline
\end{tabular}

Fig.10 Independence degree with dwelling type
室に多人数が就寝するものが 5 戸（(2) (13) (14) (15) (19) ある。また 19 戸はシャワーがなく、搵注8)を使う、あるいは公共浴場に行く (5) 6) (19) (24) (25)）などのことに不便を感じている。トイレが和式（しゃが み式) で不便な住戸が 12 戸ある。1990 年代までに建設された住戸に はシャワーがなく和式トイレのものが多い。室内の段差、増築や改 造により生じた段差やトイレに段差があるもの、家具を狭い部屋に 置き、通路が円滑に使用できないもの、また駐輪場等がなく室内に 停めているなど、室内の移動に問題がある住戸が 19 戸ある。就寝に 関わる不便は高齢者夫婦と孫が 1 ベッドに就寝する (13) (15)、夫婦が 7 $\mathrm{m}^{2}$ の住宅に就寝寸る (19)、居間で就寝する (2) (14)の 5 戸である。

自立度 II の高齢者の住戸で食事に関して支障があるもの $[\mathrm{B}]$ とし て、ガスがないため（本人＋孫）の寝室のストーブで料理を作って

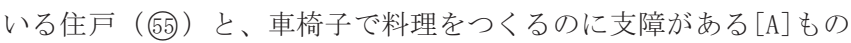
が 4 戸 (51) (58) (61) 62) ) あり、他に不便がある [B]が 9 戸 (441 (45) (49) (54) (56) (63) (64) (65) (68) ある。排泄に支障あるもの [A] が 3 戸 (49 (61 68) ) 、 不便なもの [B]が 4 戸ある (44) (55) (56) (62)）。和式であることの他、車 椅子が入れないなどの理由である。浴槽の高さ、シャワーがないな ど入浴に支障がある [A]住戸が 7 戸あり (39) (49) (55) (26) (61) (62) (68) 、不 便であるもの $[\mathrm{B}]$ が 8 戸ある。車椅子が通りにくい、段差があるため 通れないなど室内移動に支障があるもの $[\mathrm{A}]$ が 10 戸あり、段差のた め不便なもの $[\mathrm{B}]$ が 10 戸ある。就寝には $39 \mathrm{~m}^{2} の$ 平屋に 4 人（本人 十子供夫婦十孫）が住むものがある（55） [A]。また、2LDKに 8 人 が居住し、ベランダにベッドを置いているものがある（60）[A]。不 便なもの $[\mathrm{B}]$ としては 7 戸あり、2〜3 人が 1 つのベッドに就寝した り（63）、家族が高齢者を介護するため、1 寝室に 2 つのベッドを設 置する場合 ( 58 61) があり、他は居間で就寝している (51) (56) (57) (59))。

自立度 IIIIの高齢者の全ての住戸に多くの問題がある。食事は、自 分で作れず、食べられない。家族も介護ができずヘルパーが家に住 み込む必要がある。排泄も卜イレが狭く、介護のためのスペースが ない。入浴も介護スペースがない。寝たきりの高齢者が 3 人いるが、 そのうち 1 人は医療ベッドを設置しており（（73)）、部屋が狭すぎる ため移動ができない状態である。2 人は車椅子だが、介護が必要で、 狭いため就寝時など介護しにくい状態にある。

5 まとめ

本稿で明らかにした主要な点は以下である。

（1）各社区では、高齢者向けの施設を社区の事務所内に設置して いるがほとんど十分ではない。事務所が狭く、別の場所に設置する 社区もある (社区(4))。唯一施設が充実している社区(5)では、高齢者 の住居外での滞在時間が長く、孤独感は最も低く、生活満足度も高 い。施設が十分ではない地区には施設整備を行っていく必要がある。 ( 2 ) 各社区の人口密度は、258 人/ha (社区(3)） 630人/ha（社区(4) と大きく異なり、施設の設置数にばらつきがある。人口が多く、人 口密度の高い社区(4)では、施設数が少なく、孤独感が高く、満足度 も低い。また、社区の居民委員会や高齢者施設の立地に偏りがあり、 不便なケースがある（社区(1)(3)(4)(6)）。周辺に高齢者介護施設が充分 ではない社区がある (1)(2)(4)(6)。また、娛楽施設が少ないことが各 社区に共通している。施設は、周辺施設の種類や立地の状況を把握 した上で整備していく必要がある。

(3) 全体で約 $60 \%$ が空巣老人であり、72.2\%の高齢者は娛楽活動を 


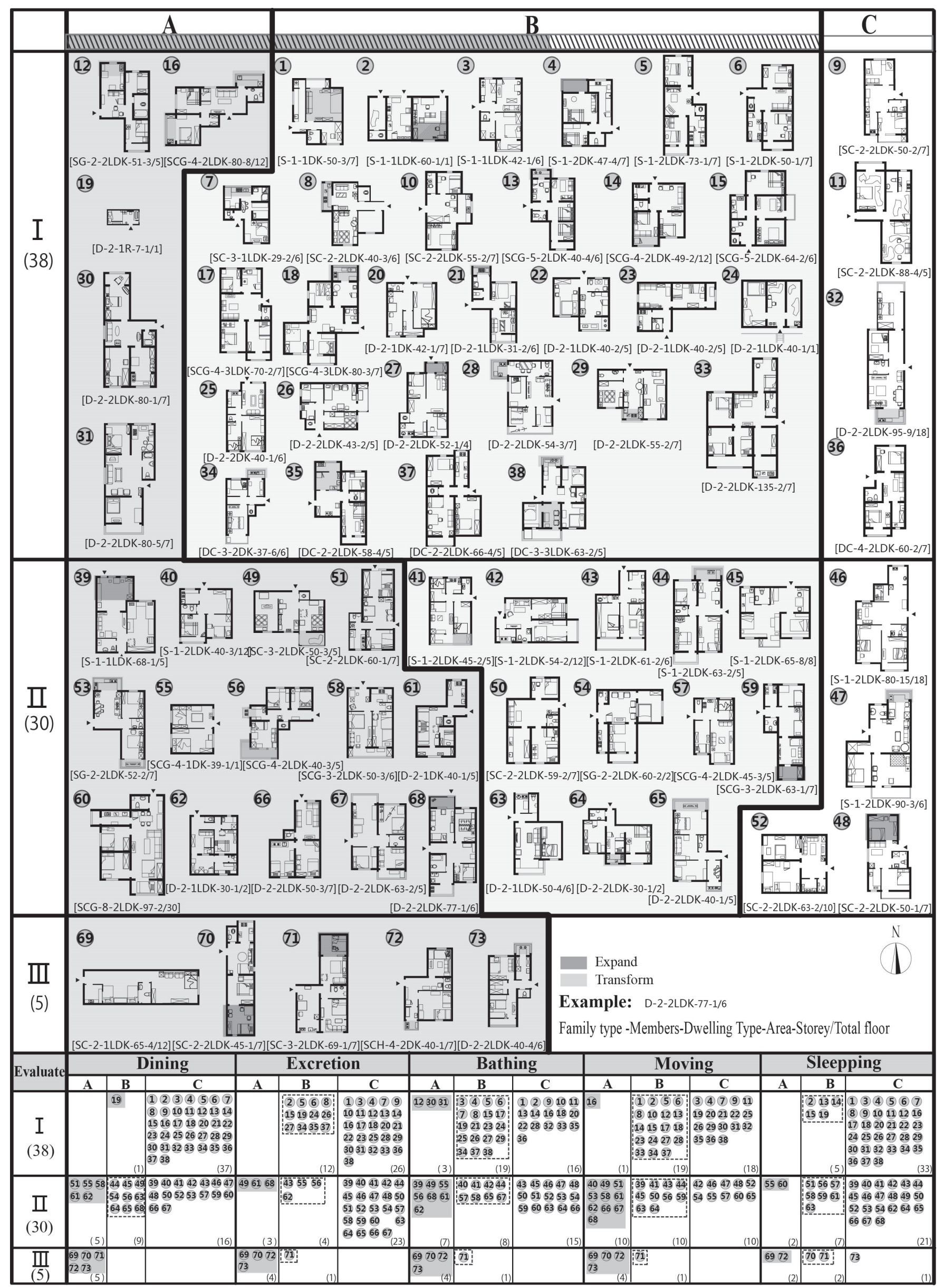

Fig.11 The evaluation of dwelling space for elderly's basic behaviors 
全く行っていない。住居外で過ごす時間も少なく、生活活動は一般 に単調である。活動に参加しない理由とする体が良くないのは 53.8\%、 また $78.1 \%$ の高齢者は慢性病を患っている。健康医療が最も重要な 関心事となっている。健康医療と繋がる体制の確立が重要である。

(4) 全体的に、4-7 階の集合住宅からなる国営企業の団地が多く 老朽化が進んでいる。また住戸は小規模で空間構成に問題がある。 エレベーターの必要性など共通の問題がある。自分の部屋を持たず リビングルームで就寝する、段差があるため体が不自由な人は移動 しにくい、面積が狭いため介護スペースがない、住戸プランには多 くの問題がみられる。住棟のエレベーターがなく、自転車や歩行器 など移動器具の安全な置き場がないことは最も大きな問題である。 シャワーがない等、また、水道電気など設備の老朽化、お風呂浴槽 の高さ等、住居の基本設備についても問題が少なくない。高齢者を 考慮した住戸計画については抜本的な見直しが必要である。

（５）高齢者の自立度が減少するに従って、居住空間の不便さ、不 都合さが増している。自立度 I の高齢者に対する居住空間の不便さ は自立度 II 、自立度III の高齢者に対しては、さらなる支障となって いる。そのうち、住戸内の移動に問題がある(「支障がある」および 「不便がある」）ものが 45 戸あり、入浴に問題があるものが 42 戸 (同上) と半数以上に問題がある。自立度吕の高齢者については、介 護システムや施設利用が早急に必要とされている。

以上、歴史都市西安の都心の社区において、高齢者の居住環境及 び住居に多くの問題があることを明らかにした。

西安の近郊住宅地および農村部については、別稿としたい。

\section{参考文献}

1) Zhigang Guo,etc.: Research on Population Ageing Situation and Development Strategy, Hualing Publishing House, pp.241-266, 2014.03 郭志剛等：人口老齢化形勢与発展戦略研究, 華齢出版社, pp. 241-266, 2014. 03

2) Renlu Hu: American Community Planning for the Elderly and It's Enlightenment, City planning, pp.58-60, 1995.03 胡仁禄：美国老年社区計画及啓示，城市計画，pp. 58-60, 1995.03

3) Liou Cao: The impact of aging population on community planning and housing construction. Urban panning international, pp.19-24, 1999.03 曹力鴎：人口老齢化対社区計画和住宅建設的影響, 国外城市計画, pp.1924, 1999.03

4) Huiqin $\mathrm{Hu}$ : Exploration of congregated dwelling house, Architectural journal, pp.12-17, 2004.10 胡慧琴 : 集合住宅的理論探索, 建筑学報, pp. 12-17, 2004.10

5) Dian Zhou, Ruoqi Zhou: Study on the way to construct "community" oriented" urban residential facilities for the aged, Architectural journal ( s 1)， pp. 74-78, 2009

周典，周若柿：構建社区化城市養老居住施設方法研究，建筑学報（s 1）, pp. 74-78, 2009

6) Tomoko Sawada: The characteristics life style and way of living for the elderly and the aged people, Journal of Architecture, Planning and Environmental Engineering (Transactions of AIJ). No.547, pp.95-102, 2001.09

沢田知子 : 熟年・高齢期におけるライフスタイルとすまい方の特徴, 長寿社 会におけるライフコースの充実・支援に向けた住宅計画, その 1 , 日本建築 学会計画系論文集, 547 号, pp. 95-102,2001.09

7) Yukiko Inoue, Kazumasa Otaki, Kazuoki Ohara: A study on life environment for the elderly who use in-honme services, Journal of Architecture, Planning and Environmental Engineering (Transactions of AIJ), No.556, pp.137-143, 2002.06

井上由起子，小滝一正，大原一興：在宅サービスを活用する高齢者のすま いに関する考察, 日本建築学会計画系論文集, 556 号, pp. 137-143, 2002. 06
8) Tatsuya Nishino, Shinji Kumaki: A case study on places of coexistence where informal supports by inhabitants are seen in a community, from the point of lives of the elderly coming to a day care center, Journal of Architecture and Planning (Transactions of AIJ) , No.642, pp.1707$1715,2009.08$

西野達也，桑木真嗣：高齢者通所施設利用者の生活からみたある地縁型地 域における地域住民らによる共助のみられる共在の場に関する事例考察， 日本建築学会計画系論文集, 642 号, pp. 1707-1715, 2009. 08

9) Tatsuya Nishino, Shizuno Nakatani: A trial study on a model of local living support environment for the elderly to continue living at their own homes through their aging changes, Journal of Architecture and Planning (Transactions of AIJ). No.691, pp.1929-1937, 2013.09 西野辰哉, 中谷静乃: 高齢者の加齢変化に対応した地域居住サポート環境の 変化とその統合モデル化の試み, 日本建築学会計画系論文集, 691 号, pp. 1929-1937, 2013. 09

10) Teruki Yamagishi, Yuji Iwakata, Masayuki Suzuki, Naoyuki Hirota, Mineki Hattori: Accessibility to local facilities of elderly people : In the case of Chiba prefecture, AIJ Journal of Technology and Design, Vol. 20, No.44, pp.257-262, 2014.02

山岸輝樹, 岩片優二, 鈴木雅之, 広田直行, 服部岑生 : 高齢者日常利用施 設に対する生活利便性に関する研究 : 千葉県内市町村の場合, 日本建築学 会技術報告集，第 20 卷，44 号，pp. 257-262，2014.02

11) Taka Kato, Masumi Matsumoto, Jun Ueno: A study on the living environment for elderly in housing estate, About the life style and housing environment of the elderly in housing setate of Tama Newtown(1), Journal of Architecture and Planning (Transactions of AIJ), No.600, pp.9-16, 2006.02

加藤田歌，松本真澄，上野淳：団地住宅における高齢者居住の様態と居住 環境整備条件について一多摩ニュータウン団地高齢者の生活像と居住環境 整備に関寸る研究その 1, 日本建築学会計画系論文集, 600 号, pp. 9-16, 2006. 02

12) Meiyu Piao, Eiji Satoh, Nobuo Mitsuhashi: A Study on continuation of old-age at own house in Shanghai, China, Journal of Architecture and Planning (Transactions of AIJ), Vol. 77, No. 682, pp.2681-2688, 2012.12. 朴美玉，佐藤栄治，三橋伸夫：中国上海市における高齢者の自宅生活の継 続可能性に関する研究, 日本建築学会計画系論文集, 第 77 巻, 682 号, pp. 2681-2688, 2012. 12

注

注 1) 空巣老人とは、子供と一緒に住んでいない高齢者（独居老人、高齢者夫 婦のみ）をいう。

注 2）「社区」は中国の都市部における最小の行政単位であり、2000 年以降、 かつて行政の末端組織として存在した「居民委員会」を合併させ、新たに 「社区居民委員会」を組織する形で設置された。

注 3）全体調查は西安市、渭南市、榆林市、商洛市の 4 市からそれぞれ 2 つず つ街道（鎮）を選択し、各街道（鎮）から 2 3 の社区（村）を選定し行っ た。西安市については、碑林区（柏樹林街道、東関南街街道）、雁塔区（小 寨路街道、等駕坡街道）、藍田県（藍関街道、普化鎮）から 11 社区、 5 村、 渭南市については、臨渭区（向陽街道、官底鎮）、蒲城県（城関鎮街道、蘇 坊鎮）から 3 社区、6 村、榆林市については、榆陽区（青山路街道、大河塔 鎮)、靖辺県 (張家畔街道、海則灘鎮) から 4 社区、5 村、商洛市について、 商州区（城関街道、沙河子鎮）、山陽県（十裏舗街道、板岩鎮）から 4 社 区、6村について調査を行った。

注 4）現在の西安市は 10 区、3 県からなる。中華人民共和国の成立とともに 発足した陝西省西安市は、当初 12 区からなっていたが、1954 年に 9 区に 改編され、一区・二区・七区が合併して碑林区が発生した。その後、1960 年 に碑林区は雁塔区に編入されるが、1962 年には再び碑林区となる。

注 5）中大路美智子：「高齢化に対応した住宅の供給」建築省建築研究所編 『あらか』），1991、pp. 13-23。

注 6）高齢者介護施設には、「三無老人」（家族、収入がなく自立できない） 向けの無料の敬老院（福利院）、有料の盖老院、医療看護付の護理院があ る。また、介護サービス付の高齢者向け集合住宅である老年公寓、日間照 料中心（デイサービスセンター）がある。

注 7）「中華人民共和国国家標準住宅建築設計規範」GBJ96 - 86，4.1.6 は、 7 階以上の住宅はエレベーターを設置することとしている。

注 8) 搵（たらい）は、湯水を入れ顔や体などを洗う容器で、洗面器より大型 のものである。 


\title{
CONSIDERATIONS ON DWELLING AND LIVING ENVIRONMENT FOR ELDERLY PEOPLE
} IN BEILIN DISTRICT OF XI'AN • CHINA

\author{
Huijuan LI ${ }^{* 1}$, Teruki YAMAGISHI ${ }^{* 2}$, Naoyuki HIROTA*3, \\ Lianru DUAN ${ }^{* 4}$ and Shuji FUNO ${ }^{* 5}$ \\ ${ }^{* 1}$ Doctoral Course, Dept. of Architecture and Architectural Engineering, Graduate School of Industrial Technology, Nihon Univ. \\ ${ }^{*}$ Senior Lect., Dept. of Architecture and Architectural Engineering, College of Industrial Technology, Nihon Univ., Dr.Eng. \\ ${ }^{* 3}$ Prof., Dept. of Architecture and Architectural Engineering, College of Industrial Technology, Nihon Univ., Dr.Eng. \\ ${ }^{* 4}$ Prof., Dept. of Architectural Engineering, College of Urban Planning and Municipal Engineering of Xi'an Polytechnic Univ., Dr.Eng. \\ ${ }^{* 5}$ Project Prof., Dept. of Architecture and Architectural Engineering, College of Industrial Technology, Nihon Univ., Dr.Eng.
}

In recent years, aging has become a serious social problem in China. It is estimated that the aging rate will reach $25.0 \%$ in China and $27.3 \%$ in Shanxi province by 2030. Moreover, the number of a couple elderly living without children and living alone elderly who are called "empty nesters elderly" in China is increasing rapidly.

The objective of this paper is to clarify and evaluate living environment, especially space formation of dwelling for elderly people in Xi'an and Shanxi, China based on field study. This paper concentrate on Beilin District of Xi'an(6 shequ). Firstly, we clarifies the space formation of shequs, distribution of public facilities in the vicinity of shequs, and public services by resident committee. Secondarily, we profiles of elderlies in general based on the interview (total 201 persons). Thirdly, we concentrate on the space formation of dwelling and clarifies the problems of dwelling accommodation for all elderlies regardless of the degree of independence.

The major points this paper clarifies are as follows.

1. Community facilities for the elderly are mostly installed in community committee's office, but are not enough. Elderly people in sheque(5) where is high aging rate, facilities is well-equipped, spends the longest time outdoor, feels the lowest loneliness and is highly satisfied with daily life. Areas lacking facilities for elderly need to be integrated.

2. The population density of each community is quite different, and the distribution of facilities are not wellbalanced. Recreational facilities are very few in general. It is necessary to integrate the area on the basis of information about the types and locations of facilities around the area.

3. $60 \%$ of the respondents are "empty nesters elderly" and $72.2 \%$ of the elderly do not participate in any recreational activities at all. The elderly have less time to stay outdoors and their activities are monotonous. $78.1 \%$ of the elderly suffer from chronic diseases and the medical health is their most concern. It is very important to establish a system of linkages with the medical system.

4. As for the planning of houses, all the dwelling have some problems. It is a basic problem that no care space and no shower etc. because the space area is so small. The problem of aging of hydroelectric heating and high bath etc. can also be pointed out. No elevator installed in the building etc.. Housing planning should consider the use of elderly that needs a fundamental change.

5. With the degree of elderly's self-independent, the inconvenience or inadaptability of living space is increasing. For the elderly people of Independent degree, there are still obstacles to use space. The inconvenience for the elderly of Independent degree I obviously becomes obstacle for the elderly of Independent degree II and III. For the elderly of Independent degreeIII, it is necessary to set up the care system and prepare facilities as soon as possible.

Above all, it is clear that there are still many problems in the living environment of the elderly in the urban center of the historic city of Xi'an. As for the suburbs and countryside area of Xi'an, other papers will be prepared. 